\title{
Cyclodorippoid crabs from the Philippines collected by the PANGLAO 2004-2005 and AURORA 2007 expeditions
}

\author{
Shane T. Ahyong ${ }^{\mathrm{a}, *}$, Peter K.L. $\mathrm{Ng}^{\mathrm{b}}$ \\ ${ }^{a}$ Australian Museum, 6 College Street, Sydney, NSW 2010, Australia \\ ${ }^{\mathrm{b}}$ Tropical Marine Science Institute, National University of Singapore, Kent Ridge, Singapore 117543, Singapore
}

Received 8 March 2011; received in revised form 3 June 2011; accepted 7 June 2011

Corresponding editor. S. De Grave.

\begin{abstract}
The cyclodorippoid crabs from the Philippines collected by the PANGLAO 2004-2005 and AURORA 2007 expeditions are reported. Five species of Cyclodorippidae are reported: Corycodus minax sp. nov., Ketamia depressa (Ihle, 1916), Krangalangia spinosa (Zarenkov, 1970), Tymolus brucei Tavares, 1991, and Xeinostoma sakaii Tavares, 1993. Corycodus minax is the second species of the genus to be recorded from the Philippines and is most similar to C. merweae Tavares, 1993, from South Africa. Krangalangia spinosa is reported for the first time from the Philippines. Sexual dimorphism in the length of the walking legs (pereopods 2 and 3) is reported for Tymolus brucei and may be a general feature of cyclodorippoids. One new species of Cymonomidae, Cymonomus liui sp. nov., is also reported, and is most similar to C. curvirostris Sakai, 1965, from Japan.

Crown Copyright $@ 2011$ Published by Elsevier GmbH. All rights reserved.
\end{abstract}

Keywords: Decapoda; Brachyura; Cyclodorippoidea; Cyclodorippidae; Cymonomidae; Corycodus; Cymonomus

\section{Introduction}

Within the Brachyura, the Cyclodorippoidea Ortmann, 1892 , occupy a unique place among the podotreme crabs as the hypothesised sister group to the Eubrachyura (Ahyong et al., 2007). A better understanding of cyclodorippoid systematics is therefore important for elucidating eubrachyuran phylogeny. Three families and 18 genera of extant cyclodorippoids are recognised worldwide (Ng et al., 2008; De Grave et al., 2009). Cyclodorippoids are often difficult to collect, however, owing to their relatively small size, cryptic habits and typically deep-water habitats. As such, the actual diversity is greatly underestimated and new species are discovered on a regular basis (e.g., Tavares, 1993; Campos, 1997; Ahyong and Brown, 2003; Ahyong et al., 2007; Ahyong

\footnotetext{
*Corresponding author.

E-mail addresses: shane.ahyong@ austmus.gov.au (S.T. Ahyong), peterng @ nus.edu.sg (P.K.L. Ng).
}

and $\mathrm{Ng}$, 2009). Important collections of two cyclodorippoid families, Cymonomidae and Cyclodorippidae, were made during the PANGLAO 2004 and 2005, and AURORA 2007 expeditions to the Philippines. Of these, the majority of the Cymonomidae have already been reported (Ahyong and $\mathrm{Ng}$, 2009). The present study reports on the Cyclodorippidae from these expeditions and a new cymonomid that was not reported by Ahyong and Ng (2009).

\section{Materials and methods}

Morphological terminology follows Ahyong and $\mathrm{Ng}$ (2009). Carapace length (cl) is the greatest length, and carapace width $(\mathrm{cw})$ is the greatest width. Postrostral carapace length (pcl), measured for Cymonomus, excludes the rostrum. Specimens are deposited in the Crustacean Collection of the National Museum of the Philippines, Manila (NMCR); Muséum national d'Histoire naturelle, Paris MNHN); and 
Raffles Museum of Biodiversity Research, National University of Singapore (ZRC).

\section{Systematic account}

\subsection{Cyclodorippoidea Ortmann, 1892}

\subsection{Cyclodorippidae Ortmann, 1892}

\subsubsection{Corycodus minax sp. nov.}

(Figs. 1 and 4B)

Corycodus sp. - Ahyong et al., 2007: tab. 1.

Material examined. Holotype, NMCR, ovigerous female (cl $5.8 \mathrm{~mm}$, cw $10.2 \mathrm{~mm}$ ), off Aligbay Island, Bohol/Sulu Sea boundary, $8^{\circ} 46.2^{\prime} \mathrm{N}, 123^{\circ} 16.1^{\prime} \mathrm{E}, 624-647 \mathrm{~m}$, PANGLAO 2005, stn CP2384-JL30, 29 May 2005. Paratype, ZRC 2006.0125, damaged female (cl $5.4 \mathrm{~mm}$, cw $9.4 \mathrm{~mm}$ ), collected together with holotype.

Description. Carapace wider than long, inflated, hexagonal in dorsal view; regions weakly indicated; surface finely granular or minutely spinular, with pair of low, blunt protogastric swellings on each side. Frontal margin sunken, finely spinose, U-shaped in anterior view; inner orbital margin produced to blunt, anteriorly directed tooth, upper orbital margin granular to dentate, with $\mathrm{V}$-shaped notch followed by distinct fissure; outer orbital margin with short blunt projections. Eye with pigmented cornea; stalk sparsely granular. Antenna not excluded from orbit, basal segment massive, surface granular or minutely spinular. Pterygostomian region swollen, granular, minutely spinose, with strong anterior spine, followed by 1 or 2 similar spines. Anterolateral margin poorly defined anteriorly, granulate or minutely denticulate along anterior half; posterior half with row of arcuate row of strong spines extending onto dorsal surface. Posterolateral and posterior margins granular but non-spinose.

Maxilliped 3 sparsely granular, spinose. Dactylus very small, shorter than propodus; carpus articulating on oral surface near distal one-third. Merus longer than ischiobasis. Ischiobasis fused, demarcation not evident. Exopod as long as ischiobasis, sparsely spinose, overreaching ischiomeral articulation.

Chelipeds finely granular. Merus and carpus unarmed. Palm about 3 times along as high, about twice as long as carpus; with 2 rows of spines on inner surface, upper row with 3 spines, lower row with 2 spines. Fingers slender, oriented obliquely to axis of palm; dactylus granular, occulsal margins with small spines, mesial margin with row of 4 spines; pollex occlusal margin with row of small spines and 4 long slender upright spines, mesial margin with row of 3 mesially directed spines.

Pereopods 2 and 3 slender, subcylindrical, longer than carapace width; segments finely granular or spinular, sparsely setose; dactyli arcuate, shorter than combined length of propodus and carpus.
Pereopods 4 and 5 subdorsal, short, slightly longer than half carapace width, segments finely granular or spinular, sparsely setose; dactyli arcuate, shorter than propodus.

Thoracic sternum longer than wide, widest at sternite 7; surface finely granular, with pair of arcuate grooves at junction of sternites 4 and 5; sternite 3 slender, fused to sternite 4, margins spinular.

Abdomen appearing swollen, surface finely granular; comprising 6 somites and telson; telson posteriorly rounded, almost twice as wide as long.

Egg large, maximum diameter $1.2 \mathrm{~mm}$ (when preserved), about 12 in number.

Colour in life. Overall off-white (Fig. 4B).

Etymology. Named minax, Latin for threatening, alluding to the 'sinister' appearance of the animal.

Remarks. Corycodus minax sp. nov. is the sixth known species of the genus. It resembles $C$. merweae Tavares, 1993 (type locality: South Africa, 32 $14.9^{\prime} \mathrm{S}, 29^{\circ} 10.4^{\prime} \mathrm{E}$, $620-560 \mathrm{~m}$ ) and differs from congeners in having prominent anterior pterygostomial spines. The new species can easily be separated from $C$. merveae in having a uniform covering of fine granules on the carapace (versus scattered and sparsely distributed); the inner orbital margin is produced to a blunt, horn-like tooth (not produced in $C$. merweae); the dorsal orbital notch is followed by a distinct fissure (absent in C. merweae); the dorsal protogastric prominence in $C$. minax is low and blunt (versus forming a conical spine in $C$. merweae); and the thoracic sternum is of a different shape, being markedly constricted only at sternite 3, rather than at both sternites 3 and 4 (cf. Tavares, 1993).

Corycodus minax is the second species of the genus to be recorded from the Philippines and the Pacific Ocean. The only other known Pacific congener, C. bouvieri Ihle,

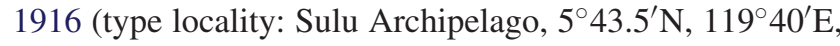
$522 \mathrm{~m}$ ), is similar to $C$. minax in general carapace ornamentation (i.e., finely granular surface and low protogastric prominence on anterolateral margin). However, C. minax is readily distinguished by the presence of 'horns' on the inner orbital margins, presence of anterior pterygostomial spines, and presence of the dorsal orbital fissure, features absent in C. bouvieri (cf. Ihle, 1916; Tavares, 1993).

Distribution. Presently known only from off Aligbay Island, Philippines; 624-647 m.

\subsubsection{Ketamia depressa (Ihle, 1916)}

(Figs. 2, 4C and 4D)

Cyclodorippe (Cyclodorippe) depressa Ihle, 1916: 131 [type locality: Sulu Archipelago, $6^{\circ} 08^{\prime} \mathrm{N}, 121^{\circ} 19^{\prime} \mathrm{E}, 275 \mathrm{~m}$, Siboga stn 105].

Cyclodorippe depressa. - Takeda and Tomida, 1984: 46.

Ketamia depressa. - Tavares, 1992: 514; 1993: 301-302, fig. 2f, 4e and f, 5c, 16a-c.

Material examined. ZRC, 1 male (cl $3.1 \mathrm{~mm}$, cw $3.2 \mathrm{~mm})$, Bolod, Bohol Sea, $9^{\circ} 32.4^{\prime} \mathrm{N} 123^{\circ} 47.8^{\prime} \mathrm{E}, 152 \mathrm{~m}$, coarse 




Fig. 1. Corycodus minax sp. nov. ovigerous female holotype, cl 5.8 mm, cw $10.2 \mathrm{~mm}$, PANGLAO 2005, stn CP2384 (NMCR). (A) Dorsal habitus, (B) orbit and antennal regions, right lateral view, (C) orbit and antennal regions, anterior view, (D) maxilliped 3, right anterior view, (E) sternum and (F) telson. Scale: $A$ and $E=2.0 \mathrm{~mm}$; B-D and $F=1.0 \mathrm{~mm}$.

sand, PANGLAO 2004, stn T2, 31 May 2004; ZRC, 1 ovigerous female (cl $2.8 \mathrm{~mm}, \mathrm{cw} 3.1 \mathrm{~mm}$ ), Bolod, Bohol Sea, $9^{\circ} 33.0^{\prime} \mathrm{N} 123^{\circ} 48.5^{\prime} \mathrm{E}, 82 \mathrm{~m}$, substrate with many large sponges, PANGLAO 2004, stn T4, 1 Jun 2004; ZRC, 2 males (cl 2.5-2.6 mm, cw 2.5-2.6 mm), 1 female (cl $2.4 \mathrm{~mm}$, cw $2.5 \mathrm{~mm}$ ), Bohol Sea between Libaong and Pamilacan Island, $9^{\circ} 31.3^{\prime} \mathrm{N}, 123^{\circ} 51.4^{\prime} \mathrm{E}, 145-163$ m, sand with echinoderms, PANGLAO 2004, stn T34, 3 Jul 2004

Remarks. The specimens agree well with published accounts (Ihle, 1916; Tavares, 1993). One specimen was found to be carrying a bivalve shell as camouflage.

Distribution. New Caledonia, Indonesia and the Philippines; 82-275 m (Tavares, 1993; this study). 


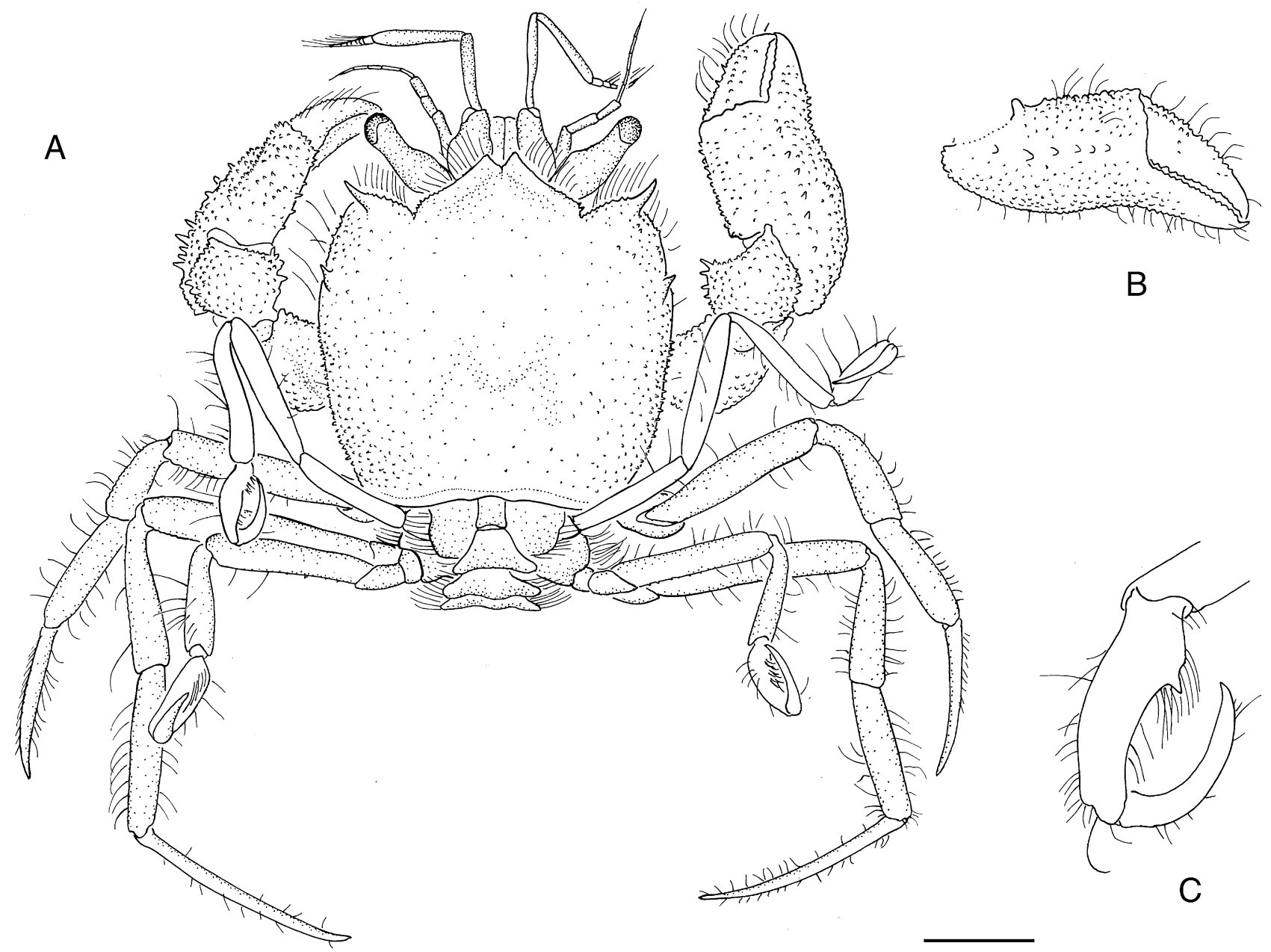

Fig. 2. Ketamia depressa (Ihle, 1916), male, cl $3.1 \mathrm{~mm}$, cw $3.2 \mathrm{~mm}$, PANGLAO, stn T2 (ZRC). (A) Dorsal habitus, (B) right chela and (C) right pereopod 4 dactylus and propodus. Scale A and $\mathrm{B}=1.0 \mathrm{~mm} ; \mathrm{C}=0.6 \mathrm{~mm}$.

\subsubsection{Krangalangia spinosa (Zarenkov, 1970)}

(Fig. 4A)

Cyclodorippe spinosa Zarenkov, 1970: 460, 1 unnumbered fig. [type locality: off west coast of Australia, $820 \mathrm{~m}$ ]. Takeda and Tomida, 1984: 46.

Cyclodorippe rostrata - Takeda and Moosa 1990: 55 [part, not Cyclodorippe rostrata Ihle, 1916].

Krangalangia spinosa - Tavares, 1992: 514; 1993: 296-299, figs. $13 \mathrm{e}, 15 \mathrm{c}$ and d.

Material examined. ZRC/NMCR/MNHN, 12 males $(\mathrm{cl}$ $4.3-4.9 \mathrm{~mm}$, cw $4.6-5.0 \mathrm{~mm}$ ), 5 females (cl $4.3 \mathrm{~mm}$, cw $4.5 \mathrm{~mm}$ ), east of Dingalan Bay, Luzon, $14^{\circ} 45.79-47.22^{\prime} \mathrm{N}$, $123^{\circ} 10.93-08.5^{\prime} \mathrm{E}, \quad 500-524 \mathrm{~m}, \quad$ AURORA 2007, stn CC2700, 27 May 2007; ZRC, 1 male (cl $4.8 \mathrm{~mm}$, cw $4.9 \mathrm{~mm}$ ), 4 females (cl 4.4-4.5 mm, cw 4.8-4.9 mm), east of Dingalan Bay, Luzon, $14^{\circ} 46.54-47.49^{\prime} \mathrm{N}, 123^{\circ} 09.69-08.28^{\prime} \mathrm{E}$, 507-540 m, AURORA 2007, stn CP2678, 500-524 m, 23 May 2007.

Remarks. The specimens correspond in most respects to published accounts (Zarenkov, 1970; Tavares, 1993), although the size of the dorsolateral carapace spine is vari- able, ranging from a small acute tubercle to a small spine, as figured by Tavares (1993) for Western Australian specimens. The spine is never as large as figured by Zarenkov (1970) and his figure appears to be somewhat stylized.

Distribution. Australia, New Caledonia, Wallis and Futuna Islands, and now from the Philippines; 479-1223 m (Tavares, 1993).

\subsubsection{Tymolus brucei Tavares, 1991}

\section{(Fig. 4E)}

Tymolus brucei Tavares, 1991: 451, figs. 2, 7, 8B, 9D, 10C [type locality: Western Australia, $18^{\circ} 52.2^{\prime} \mathrm{S}, 116^{\circ} 11.1^{\prime} \mathrm{E}$, 458-456 m]; 1993: 268, 271-272. - Chen and Sun, 2002: 171-173, fig. 73. - Ho et al., 2004: 645, Fig. 1D. - Ahyong et al., 2007: tab. 1; 2009: 165, figs. 118, 119.

Material examined. ZRC, 1 male $(\mathrm{cl} \mathrm{3.8,} \mathrm{cw} 3.9 \mathrm{~mm})$, Bohol Sea, $9^{\circ} 27.4^{\prime} \mathrm{N} 123^{\circ} 49.4^{\prime} \mathrm{E}, 273-302 \mathrm{~m}$, PANGLAO 2005, stn CP2343, 23 May 2005; ZRC/NMCR, 19 males (cl $3.8 \mathrm{~mm}$, cw $4.0 \mathrm{~mm}$ to cl $5.5 \mathrm{~mm}$, cw $6.0 \mathrm{~mm}$ ), 13 ovigerous females (cl $5.1 \mathrm{~mm}$, cw 5.4 to cl $6.1 \mathrm{~mm}$, cw $6.9 \mathrm{~mm}$ ), 14 females (cl $3.7 \mathrm{~mm}$, cw $4.0 \mathrm{~mm}$ to $\mathrm{cl} 5.3 \mathrm{~mm}$, cw $5.8 \mathrm{~mm}$ ), 
Bohol Sea, $9^{\circ} 29.4^{\prime} \mathrm{N} 123^{\circ} 44.4^{\prime} \mathrm{E}, 291-318 \mathrm{~m}$, PANGLAO 2005, stn CP2340, 23 May 2005.

Remarks. In all the specimens examined, the merus of pereopod 2 is longer than the combined lengths of the dactylus, propodus and carpus, a species characteristic of T. brucei. The proportional lengths of the pereopod 2 articles, however, exhibit allometric and sexual dimorphism. The proportional length of the merus of pereopod 2 increases with body size, and is proportionally longer in males than in size-matched females. Thus, sexual dimorphism in the length of the walking legs (pereopod 2 and 3) of T. brucei is similar to that observed for Cymonomus (Ahyong and $\mathrm{Ng}, 2009$ ) and may represent a more general pattern in cyclodorippoids.

Distribution. Western Australia, Indonesia, Vietnam, the Philippines, China and Taiwan; 220-819 m (Tavares, 1993; Ahyong and Ng, 2009).

\subsubsection{Xeinostoma sakaii Tavares, 1993}

(Fig. 4F)

Tymolus rostratus - Serène et al., 1974: 18 [not Cyclodorippe (Cyclodorippe) rostrata Ihle, 1916].

Xeinostoma euchir - Sakai, 1976: 34. - Serène and Vadon, 1981: 119, 121 [not X. euchir Stebbing, 1920].

Xeinostoma sakaii Tavares, 1993: 292-293, figs. 13c, 14b-c [type locality: Minabe, Kii Peninsula, Honshu, Japan].

Remarks. A single specimen of Xeinostoma sakaii Tavares, 1993, was collected from the Bohol Sea during

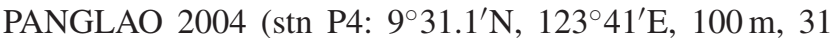
May 2004), representing the second record of the species from the Philippines. The photograph made of the fresh specimen (Fig. 4F) leaves no doubt about its identity. Unfortunately, although photographed and examined, the specimen was not available for restudy at the time of writing.

Distribution. Japan and the Philippines; 100-200 m (Tavares, 1993; this study).

\subsection{Cymonomidae Bouvier, 1898}

\subsubsection{Cymonomus liui sp. nov.}

(Figs. 3 and 4G)

Material examined. Holotype, NMCR, ovigerous female (cl $3.2 \mathrm{~mm}$, pcl $2.7 \mathrm{~mm}$, cw $3.1 \mathrm{~mm}$ ), Bohol Sea, $9^{\circ} 27.4^{\prime} \mathrm{N}$ $123^{\circ} 49.4^{\prime} \mathrm{E}, 273-302 \mathrm{~m}$, PANGLAO 2005, stn CP2343, 23 May 2005.

Description. Carapace quadrate, almost square, lateral margins slightly convergent anteriorly; regions weakly indicated; lower pterygostomian region swollen; anterior and anterolateral surfaces with few long, fine setae, other surfaces almost glabrous. Anterolateral and posterolateral surfaces covered with rounded or globular tubercles and granules, with club-shaped or stalked tubercles on anterolateral regions; tubercles largest anterolaterally, becoming smaller posterolaterally. Central carapace surface covered with small rounded tubercles, smallest on gastric and cardiac regions, larger on branchial regions. Fronto-orbital margin (exclud- ing rostrum and lateral projections) advanced very slightly beyond anterolateral margins; exceeding half anterior carapace width; lateral frontal projections elongate, situated below plane of rostrum, covered with club-shaped or stalked tubercles, slightly shorter than rostrum. Rostrum slender, apex acute, granular laterally and dorsally. Eyestalks strongly divergent, flattened, fused to carapace below rostral base; spinose; reaching anteriorly almost to apex of basal antennular peduncle segment. Epistome smooth except for blunt tubercle mesial to base of antennule and small spine mesial to base of antenna.

Antennular peduncle about $0.8 \mathrm{pcl}$; articles minutely granular. Basal antennal article fused to epistome; articles 2 and 3 with globose tubercles; article 4 smooth.

Maxilliped 3 ischiobasis subquadrate, sparsely granular, with globose tubercles; ischiobasial demarcation indistinct. Merus slightly shorter than ischiobasis, about 3.0 times longer than wide; tapering distally to rounded apex; surface and margins covered with globose and club-shaped tubercles. Dactylus, propodus and carpus sparsely spinulate or granular. Exopod not exceeding merus of endopod; covered with globose and club-shaped tubercles.

Chelipeds sparsely setose; all segments with globose and club-shaped tubercles; palm densely covered with small globose tubercles. Dactylus as long as upper palm length; with proximal dorsal granules or spinules in addition to small globose tubercles; occlusal surfaces of dactylus and pollex with scattered setae, with distinct gape when closed.

Pereopods 2 and 3 long, slender, sparsely setose; all segments except for dactylus bearing small globose and clubshaped tubercles, most pronounced along extensor margins. Pereopod 3 longest, merus 0.85 pcl. Dactyli broadly curved, extensor margin minutely granulate or spinulate; without longitudinal rib; with scattered spinules on other surfaces. Pereopod 3 dactylus distinctly shorter than combined length of propodus and carpus.

Pereopods 4 and 5 with globose and club-shaped tubercles, and minute spinules, sparsely setose; longer than merus of pereopod 3; dactyli markedly shorter than propodi, falcate, flexor margin with 2 or 3 spinules. Pereopod 5 merus, when folded against carapace, reaching midlength of carapace.

Thoracic sternites 3 and 4 covered with small globose tubercles, margins of sternites 4 and 5 with large, globose tubercles.

Abdomen densely covered with globose and club-shaped tubercles, and scattered spinules. Female pleotelson triangular, wider than long, apex rounded.

Egg diameter $0.8 \mathrm{~mm}$.

Colour in life. Overall off-white (Fig. 4A).

Etymology. Named in honour of Prof. J.-Y. Liu, in recognition of his outstanding contributions to carcinology in China, spanning a period of more then 50 years.

Remarks. With the description of $C$. liui sp. nov., 30 described species of the genus are now known worldwide (Ng et al., 2008; Ahyong, 2008; Ahyong and Ng, 2009). Cymonomus liui closely resembles C. curvirostris Sakai, 

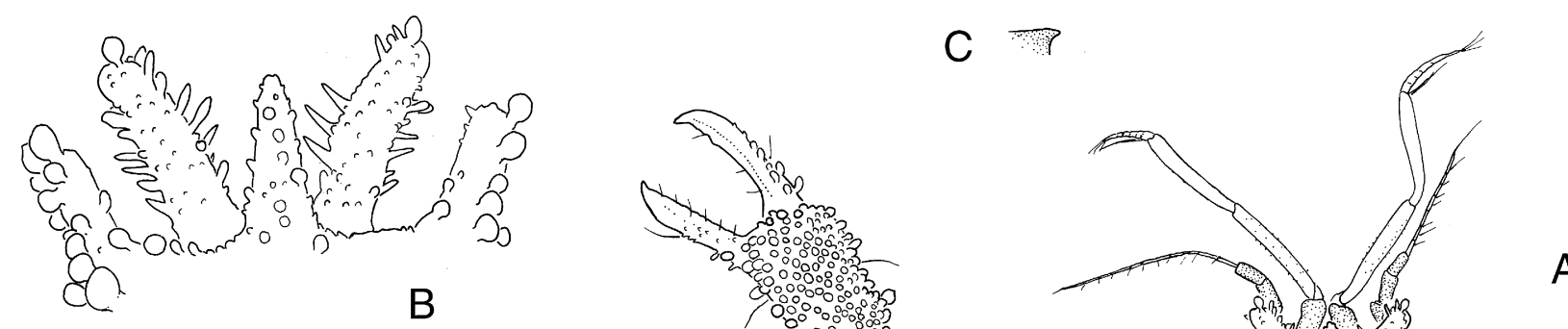

A

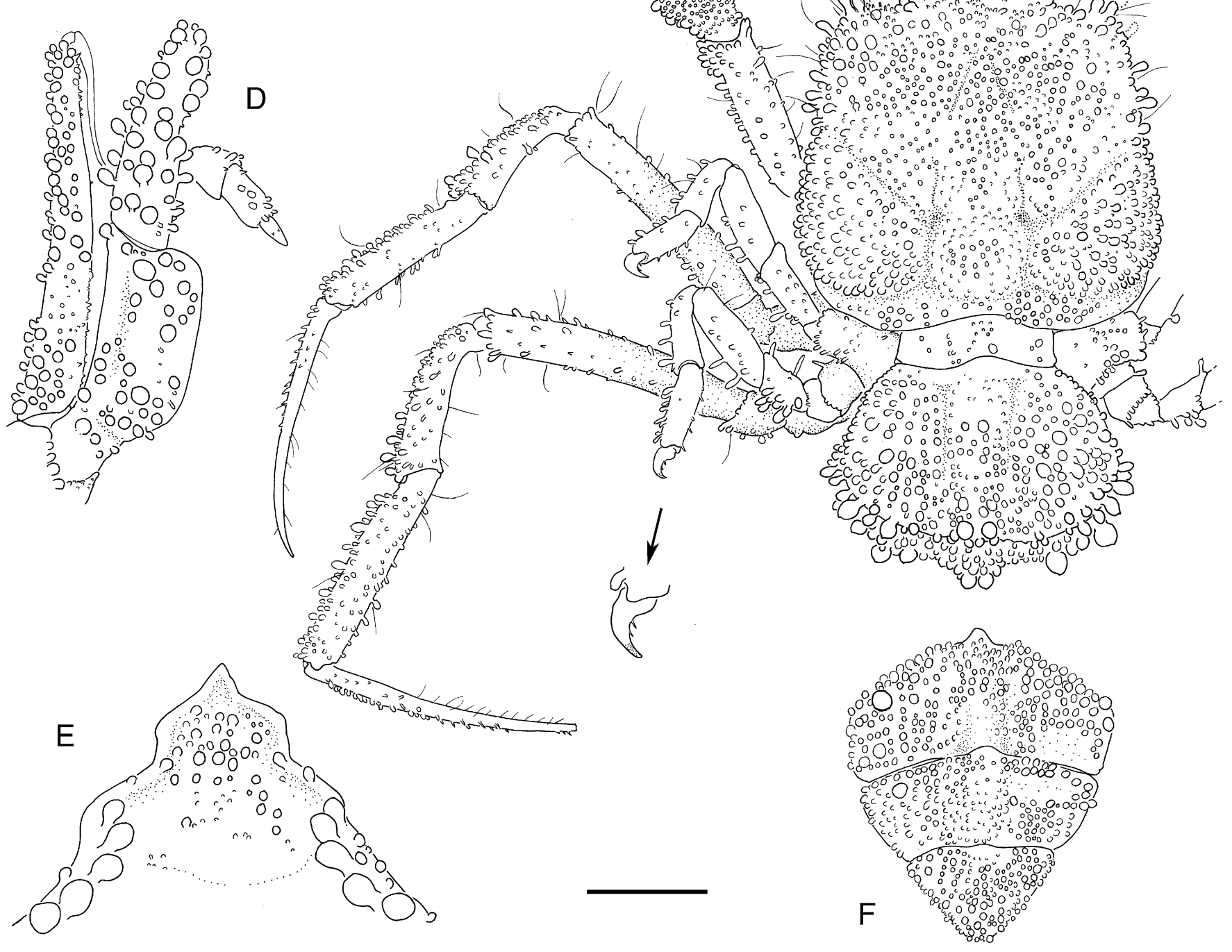

Fig. 3. Cymonomus liui sp. nov., ovigerous female holotype, cl $3.2 \mathrm{~mm}$, pcl $2.7 \mathrm{~mm}$, cw $3.1 \mathrm{~mm}$, PANGLAO 2005, stn CP2343 (NMCR). (A) Dorsal habitus, (B) anterior carapace, (C) basal antennal spine, (D) maxilliped 3, right outer view, (E) anterior sternites and (F) posterior abdomen. Scale: A and F=1.0 mm; B-E $=0.5 \mathrm{~mm}$.

1965 (Japan), C. marivenae Ahyong and Ng, 2009 (Philippines), C. trifurcus Stebbing, 1920 (South Africa) and $C$. kapala Ahyong and Brown, 2003 (Australia) in sharing the presence of pedunculate, globose tubercles on the carapace and pereopods, as well as having a diminutive size, with adults smaller than $3.5 \mathrm{~mm}$ carapace length. Cymonomus trifurcus differs from each of these species by its rostrum being longer rather than shorter than the eyestalks. Cymonomus kapala is unique in this group in bearing a large hemispherical boss laterally on each branchial margin. The new species differs from $C$. marivenae in having granulation over the entire carapace surface, rather than with the central surface smooth, and in having small, densely packed granules covering the cheliped palms, rather than large, well-spaced globose tubercles. Cymonomus liui is most similar to C. curvirostris, sharing similar carapace and pereopod ornamentations, but 


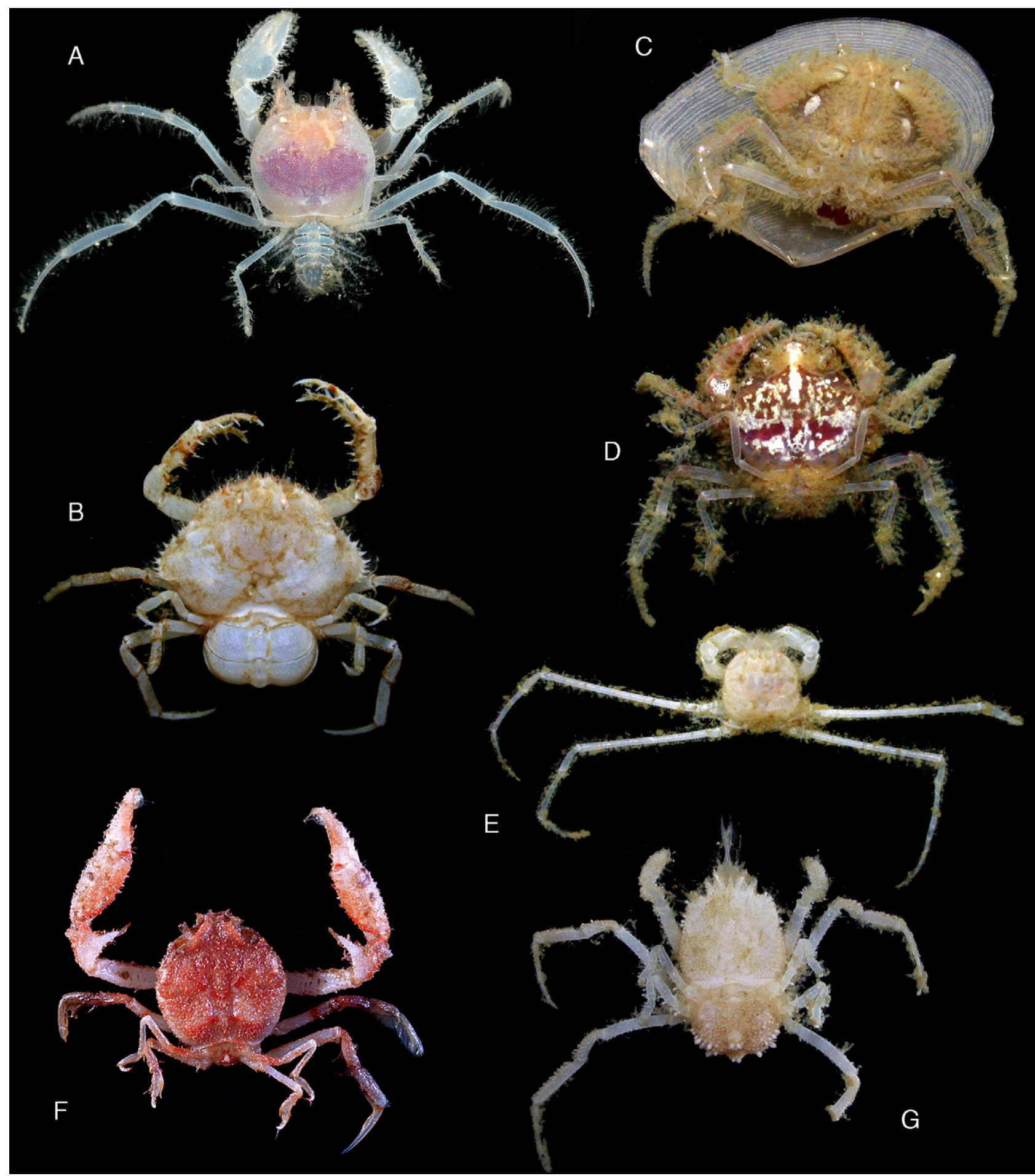

Fig. 4. Colour in life. (A) Krangalangia spinosa (Zarenkov, 1970), female, AURORA 2007, stn CP2678 (ZRC). (B) Corycodus minax sp. nov., ovigerous female holotype, cl 5.8 mm, cw 10.2 mm, PANGLAO 2005, stn CP2383 (NMCR). (C and D) Ketamia depressa (Ihle, 1916), ventral view carrying bivalve shell and dorsal view with shell removed, male, cl $3.1 \mathrm{~mm}, \mathrm{cw} 3.2 \mathrm{~mm}$, PANGLAO, stn T2 (ZRC). (E) Tymolus brucei Tavares, 1991, male, cl 3.8, cw 3.9 mm, PANGLAO 2005, stn CP2343 (ZRC). (F) Xeinostoma sakaii Tavares, 1993, PANGLAO 2004, stn P4. (G) Cymonomus liui sp. nov., ovigerous female holotype, cl $3.2 \mathrm{~mm}$, pcl $2.7 \mathrm{~mm}$, cw $3.1 \mathrm{~mm}$, PANGLAO 2005, stn CP2343 (NMCR). Photo credits: (A and F) by Tin-Yam Chan; all others by second author. 
is readily distinguished by the clear demarcation between the ocular peduncles and carapace margin. In C. curvirostris, the ocular peduncles are indistinguishably fused with the frontal margin of the carapace (cf. Sakai, 1965).

Distribution. Presently known only from the Bohol Sea, Philippines; 273-302 m.

\section{Acknowledgements}

Specimens studied here were collected during three expeditions and cruises (PANGLAO 2004, PANGLAO 2005 and AURORA 2007), organized by the Muséum national d'Histoire naturelle (MNHN, Paris); University of San Carlos (USC, Cebu); National Museum of the Philippines (NMCR, Manila); Philippines Bureau of Fisheries Research (BFAR, Manila); Raffles Museum of Biodiversity Research, National University of Singapore (RMBR); and National Taiwan Ocean University (NTOU, Keelung). We are grateful to Philippe Bouchet (MNHN), Bertrand Richer de Forges (Kiwa Consulting, New Caledonia), Danilo Largo and Lawrence Liao (USC), M. Ludivina (BFAR), Marivene Manuel-Santos (NMCR), Tan Swee Hee, Tohru Naruse, Tan Siong Kiat and Joelle Lai (RMBR), Chan Tin-Yam and Lin Chia-Wei (NTOU) for their kind help in various aspects of this study. Philippe Bouchet made all the complex arrangements necessary to facilitate the expeditions. We thank the captain and crew of the Philippine fisheries research vessel R.V. DABFAR for their kind help. The expeditions were supported by grants from the Total Foundation, French Ministry of Foreign Affairs, MNHN, RMBR and NTOU. The first author gratefully acknowledges fellowships from the Raffles Museum of Biodiversity Research, National University of Singapore.

\section{References}

Ahyong, S.T., 2008. Deepwater crabs from seamounts and chemosynthetic habitats off eastern New Zealand (Crustacea: Decapoda: Brachyura). Zootaxa 1708, 1-72.

Ahyong, S.T., Brown, D.E., 2003. New species of Cymonomus from southeastern Australia (Brachyura, Cymonomidae) with a key to the Indo-West Pacific species. Crustaceana 75, 1363-1374.

Ahyong, S.T., Lai, J.C.Y., Sharkey, D., Colgan, D.J., Ng, P.K.L., 2007. Phylogenetics of the brachyuran crabs (Crustacea: Decapoda). Part 1. The status of Podotremata based on small subunit nuclear ribosomal RNA. Molecular Phylogenetics and Evolution 45, 576-586.

Ahyong, S.T., Ng, P.K.L., 2009. The Cymonomidae of the Philippines (Crustacea: Decapoda: Brachyura), with descriptions of four new species. Raffles Bulletin of Zoology Supplement 20, 233-246.

Bouvier, E.-L., 1898. Observations on the crabs of the family Dorippidae. The Annals and Magazine of Natural History 1, 103-105 (series 7).

Campos Jr., O., 1997. Três novas espécies Brasileiras do gênero Cymonomus A. Milne Edwards, 1880 (Crustacea, Brachyura,
Podotremata). Trabalhos do Instituto Oceanografico da Universidade Federal de Pernambuco, Recife 25, 127-135.

Chen, H., Sun, H., 2002. Marine primitive crabs, Brachyura, Arthropoda Crustacea. Fauna Sinica: Invertebrata 30, 1-597 [pls 1-16 (in Chinese with English summary)].

De Grave, S., Pentcheff, N.D., Ahyong, S.T., Chan, T.-Y., Crandall, K.A., Dworschak, P.C., Felder, D.L., Feldmann, R.M., Fransen, C.H.J.M., Goulding, L.Y.D., Lemaitre, R., Low, M.E.Y., Martin, J.W., Ng, P.K.L., Schweitzer, C.E., Tan, S.H., Tshudy, D., Wetzer, R., 2009. A classification of living and fossil genera of decapod Crustaceans. Raffles Bulletin of Zoology Supplement 21, 1-109.

Ho, P.-H., Ng, P.K.L., Chan, T.-Y., Lee, D.-A., 2004. New records of 31 species of brachyuran crabs from the joint Taiwan-France expeditions, "TAIWAN 2000" and "TAIWAN 2001", off deep waters in Taiwan. Crustaceana 77, 641-668.

Ihle, J.E.W., 1916. Die Decapoda Brachyura der Siboga-Expedition. II. Oxystomata, Dorippidae. Siboga-Expeditie Monograph 39B1, 97-158.

Ng, P.K.L., Guinot, D., Davie, P.J.F., 2008. Systema Brachyurorum. Part I. An annotated checklist of extant brachyuran crabs of the world. Raffles Bulletin of Zoology Supplement 17, $1-286$.

Ortmann, A.E., 1892. Die Decapoden-Krebse des Strassburger Museums, mit besonderer Berücksichtigung der von Herrn Dr. Döderlein bei Japan und bei den Liu-Kiu-Inseln gesammelten und zur Zeit im Strassburger Museum aufbewahrten Formen. V Theil. Die Abtheilungen Hippidea, Dromiidea und Oxystomata. Zoologische Jahrbücher, Abteilung für Systematik. Geographie und Biologie der Thiere 6, 532-588.

Sakai, T., 1965. The Crabs of Sagami Bay, collected by His Majesty the Emperor of Japan, i-xvi, 1-206, 1-92, 1-32, figs. 1-27, pls. 1-100. Maruzen, Tokyo.

Sakai, T., 1976. Crabs of Japan and the Adjacent Seas. In three volumes; English text, i-xxix, 1-773, Japanese text, 1-461, Plates volume, 1-16, pls. 1-251. Kodansha, Tokyo.

Serène, R., Romimohtarto, R., Moosa, M.K., 1974. The Hippidea and Brachyura collected by the Rumphius Expedition I. In: Report on the Rumphius Expedition I (January-February 1, 1973). Oseanologi Indonesia 1, 17-26.

Serène, R., Vadon, C., 1981. Crustacés Décapodes: Brachyoures. Liste préliminaire, description de formes nouvelles et remarques taxonomiques. In: Crosnier, A. (Ed.), Résultats de Campagnes MUSORSTOM volume 1 - Philippines (18-28 mars 1976). Mémoires du Muséum national d'Histoire naturelle, Paris 91, 117-140, pl. 1-4.

Stebbing, T.R.R., 1920. South African Crustacea (Part X of S.A. Crustacea, for the Marine Investigations in South Africa). Annals of the South African Museum 17 (4), 231-272.

Takeda, M., Tomida, S., 1984. Two new fossil crabs of the Tymolidae from the Miocene Mizunami Group, Central Japan. Bulletin of the Mizunami Fossil Museum 11, 39-49, pl. 13.

Tavares, M., 1991. Révision préliminaire du genre Tymolus Stimpson, avec la description de Tymolus brucei sp. nov. d' Australie occidentale (Crustacea, Brachyura, Cyclodorippoidea). Bulletin du Muséum national d'Histoire naturelle, Paris, séries 4, section A, Zoologie 13, 439-456.

Tavares, M.S., 1992. Tendances évolutives chez les Crabes primitifs, avec la description d'un nouveau type de chamber incuba- 
trice (Crustacea, Decapoda: Cyclodorippinae Ortmann, 1892, et Xeinostomatinae subfam. nov.). Comptes Rendus Hebdomadaires des Seances de l'Academie des Sciences 312, 509-514 (series 3).

Tavares, M., 1993. Crustacea Decapoda: Les Cyclodorippidae et Cymonomidae de l'Indo-Ouest-Pacifique à l'exclusion du genre Cymonomus. In: Crosnier, A. (Ed.), Résultats des Campagnes MUSORSTOM, vol. 10. Mémoires du Muséum national d'Histoire naturelle, Paris 156, 253-313.

Zarenkov, N.A., 1970. A new deep-water species of crabs from the genus Cyclodorippe (Dorippidae). Zoologichesky Zhurnal 49, 460-462. 